\title{
Huzurevinde Kalan Yaşlılarda Depresyon ve Benlik Saygısı İlişkisi
}

\author{
Dr. Öğr. Üyesi Emre YILMAZ* \\ Bülent Ecevit Üniversitesi, İlahiyat Fakültesi, Felsefe ve Din Bilimleri Bölümü, Zonguldak / Türkiye \\ eyilmaz2007@hotmail.com, ORCID: 0000-0002-1684-9821
}

\section{$\ddot{\mathbf{O} z}$}

$\mathrm{Bu}$ çalışma, huzurevinde yaşayan 60 yaşın üzerindeki yaşlı bireylerin depresyon ve benlik saygısı düzeylerini belirlemek vebazı demografik değişkenlerle depresyon ve benlik saygısı düzeyleri arasındailişki olup olmadığını tespit etmek amacıyla tanımlayıcı nitelikte yapılmış bir alan araştırmasıdır. Araştırmanın evrenini ve örnekleminiBilecik Huzurevi Yaşlı Bakım ve Rehabilitasyon Merkezinde Huzurevi biriminde kalan (sürekli bakım hizmeti alanlar hariç) 33 yaşlı birey oluşturmaktadır. Araştırma Ekim-Kasım 2017 tarihlerinde gerçekleştirilmiştir. Araştırmada verilerin toplanması noktasında, Kişisel Bilgi Formu, depresyon düzeyini ölçmede kullanılan Geriatric Depresyon Ölçeği ve benlik saygısı düzeylerini belirlemek amacıyla, Füsun Çuhadaroğlu tarafından Türkçeye çevrilmiş olan Rosenberg Benlik Saygısı kullanılmıştır. Araştırmadan elde edilen verilerin istatistiksel olarak değerlendirilmesinde; frekans analizi, yüzdelik hesaplaması, ortalama, standart sapma, minimum ve maksimum değerlerini göstermek için ise Descriptive Analizi uygulanmıştır. İki değişken arasındaki ilişkinin yönü ve şiddetini hesaplamak için ise korelasyon analizinden yararlanılmıştır. Kullanılan ölçeklerin araştırmaya katılanların demografik bilgilerine göre farklılık gösterip göstermediği Student $\mathrm{T}$ testi ve $\mathrm{F}$ testleri/Varyans analizi (ANOVA) ile test

* Tel: +90 5464291787

(C) 2018 Kalem Eğitim ve Sağlık Hizmetleri Vakfı. Bütün Hakları Saklıdır. 
edilmiştir. Huzurevinde kalan yaşlı bireylerin depresyon düzeyinin yüksek olduğu (18.53 \pm 7.16 ), yaşlıların \%70'inin kesin depresyon belirtisi gösterdikleri ve depresyon düzeyinin kadınlarda (23.22) erkeklere göre (16.52) daha yüksek düzeyde olduğu, benlik saygısı ile depresyon arasında negatif anlamlı bir ilişkinin olduğu $(p<0.05$, $\mathrm{r}=0.635$ ), huzurevinde kalan yaşlıların depresyon düzeyleri yükseldikçe benlik saygısı düzeylerinin düştüğü, huzurevinde yaşayan yaşlı bireylerin depresyon düzeyinin sosyal uğraşlara katılma durumuna göre anlamlı farklılık gösterdiği $(p=0.003<0.005)$, sosyal uğraşlara hiç katılmayan yaşlıların depresyon düzeyinin (23.41), sosyal uğraşlara bazen katılan yaşlılara göre (15.62) daha yüksek düzeyde olduğu $(p=0.003<0.005)$, huzurevinde kalan yaşlıların benlik saygısı düzeyinin sosyal uğraşlara katılma durumuna göre anlamlı farklılık gösterdiği $(p=0.002<0.005)$, sosyal uğraşlara hiç katılmayan yaşlıların benlik saygısının (4.08) diğer yaşlılara göre (2.12) daha düşük düzeyde olduğu tespit edilmiştir.

Anahtar Kelimeler: Huzurevi; Depresyon; Geriatrik depresyon ölçeği; Benlik saygısı; Rosenberg benlik saygısı ölçeği.

\title{
Relation of Depression and Self-Esteem in Older Nursing Homes
}

\begin{abstract}
This study is a descriptive field study to determine depression and selfesteem levels of elderly people over age 60 living in nursing homes and to determine whether there is a relationship between some demographic variables and depression and self-esteem levels. The universe and sample of the research consists of 33 elderly individuals (except those who are in continuous care) who stay in the Bilecik Nursing Home Elderly Care and Rehabilitation Center. The study was conducted between October and November 2017. The Personal Information Form, the Geriatric Depression Scale used to measure depression level and the Rosenberg Self Respect translated into Turkish by Füsun Çuhadaroğlu were used to determine the level of self-esteem. In the statistical evaluation of the data obtained from the research; Descriptive Analysis is applied to show frequency analysis, percentile calculation, mean, standard deviation, minimum and maximum values. Correlation analysis was used to calculate the direction and severity of the relationship between the two variables. Student $\mathrm{T}$ test and $\mathrm{F}$ tests/ANOVA were used to test whether the scales used differed according to the demographic
\end{abstract}


information of the participants. The elderly people living in nursing homes had a high level of depression (18.53 \pm 7.16$), 70 \%$ of the elderly showed a definite depression and the level of depression was higher in women (23.22) than in men (16.52) $(p<0.05, \mathrm{r}=0.635)$, depression levels decreased as depression levels of the elderly residents increased, depression level of elderly people living in nursing homes showed a significant difference according to social involvement status $(p=0.003<0.005)$, the level of depression of the elderly who never participated in social activities (23.41) was higher than that of elderly people who participated in social activities $(15.62)(p=0.003<0.005)$, the level of self-esteem of the elderly $(p=0.002<0.005)$, whereas those who never participated in social activities it was found that the self-esteem (4.08) of the adolescents was lower than other ages (2.12).

Keywords: Nursing home; Depression; Geriatric depression scale; Self esteem; Rosenberg self esteem scale.

\section{Extended Summary}

\section{Purpose}

This study is a descriptive and cross-sectional study to determine the depression and self-esteem levels of elderly people over age 60 living in nursing homes and to determine whether there is a relationship between some socio-demographic variables and depression and self-esteem levels.

Thirty-three elderly individuals (except for those who are undergoing continuous care) in the nursing home unit of Bilecik Nursing Home for the Elderly and $30(90.9 \%)$ elderly individuals voluntarily accepted to participate in the study.

\section{Materials and Method}

The research is descriptive and cross-sectional, and the Ministry of Family and Social Policies has officially requested permission from the Provincial Directorate of Bilecik and in cooperation with the Founding Director of the Nursing Home and the Psychological Rest Home, Bilecik Nursing Home Care and Rehabilitation Center It was conducted by interviewing the elderly.

A Geriatric Depression Scale consisting of 30 questions was used by the Füsun Çuhadaroğlu in order to determine the socio-demographic characteristics of the sample group and to determine the level of self-esteem in order to measure the level of self-esteem in the elderly and a Rosenberg Self- 
Consciousness consisting of 10 questions.

The data obtained from the research were uploaded to the SPSS 21.0 package program and analyzed. In the statistical evaluation of the data obtained from the research; Descriptive Analysis is applied to show frequency analysis, percentile calculation, mean, standard deviation, minimum and maximum values. Correlation analysis was used to calculate the direction and severity of the relationship between the two variables. Student $T$ test and $F$ tests/ANOVA were used to test whether the scales used differed according to the demographic information of the participants.

\section{Findings}

$30 \%$ of the elderly participated in the research in the nursing home and $70 \%$ are men. $43.3 \%$ of the elderly are aged $60-70,23.3 \%$ are $71-80,30 \%$ are between $81-90$ years and 3.3\% are over 91 years old, when the educational status of the elderly is examined $10 \%$ are not literate, $13.3 \%$ are literate, $53.3 \%$ are primary school educated, $10 \%$ are middle school educated, $6.7 \%$ are high school educated, $6.7 \%$ while $6.7 \%$ of elderly people frequently hear the request to participate in social activities, 53.3\% sometimes feel desire and $40 \%$ do not feel any desire, while watching the elderly more time and watching radio, listening, resting and chatting, 56\% cannot do their own care alone, $16 \%$ do not have females, and $28 \%$ prefer to stay in the institution because of economic reasons.

\section{Discussion and Conclusion}

Elderly people living in nursing homes have high depression level $(18.53 \pm 7.16), 70 \%$ of elderly patients show definite depression and depression level is higher in women (23.22) than men (16.52) $(p<0.05, \mathrm{r}=0.635)$, depression levels decreased as the depression levels of the elderly residents increased and depression level of the elderly people living in the nursing home showed a significant difference according to the social participation status $(p=0.003<0.005)$, the level of depression of the elderly who never participated in social activities (23.41) was higher than that of elderly people who participated in social activities $(15.62)(p=0.003<0.005)$, the level of self-esteem of the elderly $(p=0.002<0.005)$, there was no significant difference in social activities (4.08) were found to be lower than the other ages (2.12). 


\section{Giriş}

Ülkemizde geleneksel olarak yaşlı bireylerin ailesi ve çocukları ile birlikte yaşaması eğilimi yüksek olmakla birlikte, son yıllarda çekirdek aile yapısına doğru bir değişimin olması huzurevinde yaşayan bireylerin sayısında önemli oranda bir artışa neden olmuştur (Aksüllü ve Doğan, 2004; Zincir, Taş̧̧1, Erten ve Başer, 2008).

$\mathrm{Bu}$ çalışma, huzurevinde yaşayan 60 yaşın üzerindeki yaşlı bireylerin sosyo-demografik özelliklerini, depresyon (depresif belirti) ve benlik saygis1 düzeylerini, bu iki değişkenin sosyo-demografik değişkenlere göre farklılık gösterip göstermediğini saptamak ve benlik saygısı-depresyon arasında ilişki olup olmadığını tespit etmek amacıyla tanımlayıcı nitelikte bir alan araştırmasidir.

Depresyon, psikiyatrik geriatri alanında en sık karşılaşılan sorunlardan birisidir (Altay ve Avcı 2009; Hacıhasanoğlu ve Yıldırım, 2009; Yıldız, Erol ve Ergün, 2009). Yaşlanma ile bedensel hastalıkların yanı sıra, depresyon gibi ruhsal hastalıklar da görülebilmektedir. Türkiye'de geriatri ve depresyon birlikteliğini ortaya koyan ve huzurevlerinde yaşayan bireylerde yapılmış araştırmalardan elde edilen veriler, yaşlı ve huzurevlerinde yaşayan bireylerde, depresyon görülme oranının yüksek olduğunu ortaya çıkarmıştır (Aksüllü ve Doğan, 2004; Altay ve Avcı, 2009; Maral, Aslan, İlhan, Yıldırım, Candansavar ve Bumin, 2001).

Yaşlılarda depresyonun varlığı bireyde yaşın getirmiş olduğu bedensel hastalıkların daha fazla alevlenmesine ve bu hastalıklara bağlı ölümlerin artmasına yol açar. Yine bu yaş grubunda depresyon yeti yitimine ve buna bağlı bakım ve sosyal destek gereksinimine yol açmakta ve böylelikle yaşam kalitesini düşürmekte ve bireylerin benlik saygılarına olumsuz etki etmektedir (Baripoğlu, 2008).

\section{Araştırmanın Amacı ve Önemi}

Araştırmanın temel amacı, huzurevlerinde kalan yaşlı bireylerin nasıl bir sosyo-demografik yapıya sahip olduğu, yaşlıların benlik saygıları ile depresyon olguları arasında bir ilişkinin olup olmadığını, ilişki varsa bu ilişkinin ne derece ve hangi düzeyde anlamlı olduğunu, yaşlılardan alınan veriler doğrultusunda tespit etmektir. Araştırmanın bir diğer amacı ise, benlik saygısı ve depresyon olgularının bazı demografik değişkenlere göre farklılaşıp farklılaşmadığını saptamaktır. 
Araştırma, benlik saygısı ile depresyonun ne ölçüde ilişkili olduğu, hayatlarının yaşl11ık dönemini huzurevlerinde ailesi ve sevdiklerinden uzakta geçiren yaşlı bireylerin depresyon düzeylerinin benlik saygıları üzerinde rolünün ne olduğunu tespit etmeye çalışan bir çalışma olması sebebiyle önem arz etmektedir.

\section{Yöntem}

\section{Araştırmanın Modeli}

Huzurevlerinde kalan yaşlı bireylerin depresyon ve benlik saygısı arasında anlamlı bir ilişki olup olmadığı araştırılırken birçok bilimsel araştırma metot ve teknikleri kullanılmış ve benlik saygısı-depresyon ilişkileri, sebepsonuç ilişkisi şeklinde değil, her biri ayrı bir bütünlük teşkil eden iki fenomen arasındaki ilişkiler şeklinde ele alınmıştır. Bu nedenle araştırmada, iki ya da daha fazla değişken arasındaki ilişkinin varlığını ortaya çıkarmakta kullanılan nicel araştırma yöntemlerinden survey/tarama (Karasar, 2005) yönteminin bir çeşidi olan İlişkisel Tarama Modeli kullanılmıştır (Büyüköztürk, Akgün, Karadeniz, Demirel ve Çakmak, 2014). Bu doğrultuda araştırmanın amacı ve belirlediğimiz hipotezler doğrultusunda, öncelikle "depresyon” bağımsız değişken, "benlik saygısı" bağımlı değişken olarak alınarak "depresyon" ve "benlik saygısı" arasındaki korelasyonlar hesaplanmış, ikinci olarak ise sosyo-demografik özellikler bağımsız değişken, "depresyon" ve "benlik saygısı" bağımlı değişken olarak alınarak depresyon ve benlik saygısı değişkenlerinin ayrı ayrı demografik değişkenlerle ilgili analizleri yapılmıştır.

\section{Evren ve Örneklem}

Araştırmanın evrenini Bilecik Huzurevi Yaşlı Bakım ve Rehabilitasyon Merkezi'nde huzurevi biriminde kalan (sürekli bakım hizmeti alanlar hariç) 33 yaşlı birey, örneklemini ise çalışmaya katılmayı gönüllü olarak kabul eden toplam $30(\% 90.9)$ yaşlı birey oluşturmaktadır. Bu çalışmada evrenin ulaşılabilir sayıda olmasından dolayı örneklem seçim yöntemine gidilmemiş, evrenin tamamı örneklem grubuna alınmış, huzurevinde kalan yaşlılardan sürekli bakım ünitesinde yatağa bağımlı olup sözel iletişime geçemeyenler dışındaki kendileriyle iletişim kurulabilen 60 yaş üstü 30 (\%90.9) yaşlı birey araştırmanın evrenini ve aynı zamanda da örneklemini oluşturmaktadır.

Aile ve Sosyal Politikalar Bakanlığı resmî internet sitesinde bulunan istatistikî verilerde Bilecik Huzurevinin yatak kapasitesi 87 olup toplam 79 kişi bu kurumda kalmakta ve bu sayının da 33'ü huzurevi biriminde, diğer 46'sı ise sürekli bakım ünitesinde kalmaktadır. 


\section{Hipotezler}

Benlik saygısı ve depresyonun çeşitli demografik özelliklere göre farkl11ık gösterip göstermediğinin ve söz konusu iki değişken (Benlik SaygısıDepresyon) arasındaki ilişkinin incelendiği bu araştırmada şu hipotezler ileri sürülmüştür:

1. Huzurevinde kalan yaşı bireylerin depresyon düzeyleri ile benlik saygısı düzeyleri arasında negatif yönde anlamlı bir ilişki vardır. Katılımcıların depresyon düzeyi puanları arttıkça benlik saygısı düzeyinde düşüş olması beklenmektedir.

2. Huzurevinde kalan yaşlı bireylerin depresyon ve benlik saygısı düzeyi ile sosyo-demografik değişkenler arasında anlamlı bir ilişki/farklılık olması beklenmektedir.

3. Huzurevinde kalan yaşlı bireylerin depresyon düzeyleri yüksektir.

4. Huzurevlerinde kalan yaşlı bayanların depresyon düzeyi erkeklere göre daha yüksek düzeydedir.

Esas olarak iki ana değişken (depresyon ve benlik saygısı) arasındaki ilişkinin durumunu tespit etmeyi amaçlayan bu araştırmada yukarıda ifade edilen denencelerin test edilmesinin yanı sıra şu alt problemlere de cevap aranacaktır:

1. Araştırmaya katılan yaşlılar sosyo-demografik değişkenler açısından nasıl bir dağılım göstermektedirler?

2. Araştırmaya katılan yaşlı bireyler depresyon ve benlik saygısı düzeyleri bakımından nasıl bir dağılım göstermektedirler?

3. Araştırmaya katılan yaşlı bireylerin depresyon düzeyleri ile benlik saygısı düzeyleri arasında anlamlı bir ilişki var mıdır?

4. Huzurevinde kalan yaşlı bireylerin depresyon düzeyleri ve benlik saygısı (özsayg1) düzeyleri, sosyo-demografik değişkenlere göre farklılaşmakta mıdır? Yani sosyo-demografik değişkenler ile depresyon düzeyleri ve benlik saygısı düzeyleri arasında önemli ve anlamlı bir fark var midır? 


\section{Araştırmanın Varsayımları}

Araştırmanın varsayımları şunlardır:

1. Araştırma konusunun temel kavramlarından birisi olan, kişinin kendisini olduğu gibi kabul etmesi ve saygı duymasını ifade eden, bireyin kişiliğinin öznel yanına vurgu yapan "benlik saygısı", psikometrik bağlamda ölçülebilen yapıya sahip bir kavramdır.

2. Yine araştırma konusunun temel kavramlarından olan "depresyon" olgusu niteliksel olarak ölçülebilen bir kavramdır.

3. Araştırmanın evren ve örneklemini oluşturan yaşlıların, depresyon ve benlik saygısı ölçme araçlarının yer aldığı anket formundaki soruları içtenlikle ve samimiyetle cevapladıkları kabul edilmektedir.

4. Araştırmada kullanılan "Geriatric (Yaşlı) Depresyon Ölçeği”"nin huzurevinde kalan yaşl1ların depresyon düzeylerini, "Rosenberg Benlik Saygısı Ölçeği”nin yaşlı bireylerin benlik saygısı düzeyini ölçmek için yeterli, geçerli ve güvenilir bir ölçme aracı olduğu kabul edilmektedir.

\section{Araştırmanın Sınırlılıkları}

Söz konusu araştırma insan merkezli bir çalışma olduğundan, sosyal bilimler alanında insan merkeze alınarak yapılan tüm araştırmalarda geçerli olan sinırlılıklar ile anket tekniği ve istatistikler için geçerli olan tüm sınırl1lıklar, bu araştırma için de geçerlidir.

$\mathrm{Bu}$ doğrultuda araştırmanın temel sınırlılıklarını şöyle sıralamak mümkündür:

1. Ülkemizdeki Huzurevlerinde toplam 8.914'ü normal bakım, 5.525'i özel bakım olmak üzere toplam 14.439 yaşlı birey yaşamaktadır. Hepsi ile anket çalışması yapmamızın imkânsızlığı nedeniyle araştırmamız, Bilecik Huzurevi'nde kalan, farklı demografik özelliklere sahip ve gönüllü olarak çalışmamıza katılmış 60 yaş üstü bireylerde depresyon düzeyini araştıran bir alan araştırmasıdır. Bu sebeple araştırma sonunda elde edilen sonuçlar kendi evreni ve örneklem grubu ile yani anket uygulamasında bulunduğumuz 30 yaşlı birey ile sinirlıdir.

2. Araştırmamızla ilgili bir başka sınırlılık çalışmanın belirli bir zaman aralığında yapılmış olmasından kaynaklanan sınırlılıktır. Araştırmamızın anket çalışması Bilecik il merkezinde bulunan huzurevinde kalan yaşlılara, 2017 yılı Ekim ayında uygulanmış ve katılımcılara anket sorularına cevap verirken 
yaşadıkları son 1 haftayı göz önünde bulundurarak cevap vermeleri istendiğinden, araştırmamız sadece çalışmayı yaptığımız bu zaman diliminde alınan cevaplara bağlı olması bakımından sınırlılık arz etmektedir.

3. Araştırma bulguları, kullanılan anket ve ölçek formları (Geriatrik Depresyon Ölçeği ve Rosenberg Benlik Saygısı Ölçeği) ile örneklemin anket ve ölçek maddelerine verdikleri cevaplardan elde edilen verilerle sınırlıdır.

\section{Veri Toplama Araçları}

Araştırmada verilerin toplanması noktasında, örneklem grubunun sosyo-demografik özelliklerine ilişkin bilgiler edinmek amaciyla 22 soruluk Kişisel Bilgi Formu ve karşılıklı ilişkinin düzeyini ölçmek maksadıyla, yaşl1ların depresyon düzeyini ölçmede kullanılan ve 30 sorudan oluşan Geriatric Depresyon Ölçeği, benlik saygısı düzeylerini belirlemek amacıyla, Füsun Çuhadaroğlu tarafindan Türkçeye çevrilmiş ve 10 sorudan oluşan Rosenberg Benlik Saygısı ölçeklerinden yararlanılmış ve bu ölçeklerin hepsi tek bir formda birleştirilerek katılımcılara uygulanmıştır.

Kişisel Bilgi Formu: Araştırmada huzurevinde kalan yaşlı bireylerin "cinsiyet, yaş, medenî durum, en uzun süre yaşadığı yer, eğitim durumu, gelir durumu, kurumda kalma süresi, çocuğu olup olmama durumu, çocuklarla görüşme s1klığı (yüz yüze/telefonla), meslek dağılımı, herhangi bir sosyal güvence durumu, ziyaret edilme sıklığı, odayı paylaşma durumu, kurumda kalma sebebi, kurumda vakit geçirme durumu, sosyal uğraşlara katılma isteği, kurum dışına çıkma sıklı̆̆ı, kronik hastalık durumu, sürekli ilaç kullanım durumu" hakkında bilgiler edinmeyi amaçlayan ve 20 adet sorudan oluşan "Kişisel Bilgi Formu" kullanılmıştır.

Geriatrik Depresyon Ölçeği (GDÖ): Geriatrik Depresyon Ölçeği, Yesavage ve arkadaşları tarafindan 1983 yılında geliştirilerek geçerlilik ve güvenirlik çalışması yapılmış (Yesavage ve ark., 1983), ölçeğin ülkemizde de Ertan, Eker ve Şar tarafindan 1997 yılında (test-tekrar test tutarlılığı, $\mathrm{r}=0.77$; iç tutarlılık $\mathrm{a}=0.92$ ) ve Sağduyu tarafından 1997 yılında (test-tekrar test tutarlı1ığı, $\mathrm{r}=0.87$; iç tutarlılık a=0.72) (Sağduyu, 1997) geçerlik ve güvenilirlik çalışması yapılmış, yaşlı nüfusa yönelik bir depresyon ölçeğidir.

Geriatrik Depresyon Ölçeği, öz bildirime dayalı 30 sorudan oluşan ve yaşlıların kolayca işaretleyebileceği, evet/hayır biçiminde yanıtlanması istenen bir ölçektir. Ölçeğin puanlanmasında depresyon lehine verilen her yanıt için 1 puan, diğer yanıt için 0 puan verilmekte ve toplam puan depresyon puanı 
olarak kabul edilmektedir. Ölçekten alınabilecek puanlar 0-30 arasındadır. Ölçeğin puanlanması; 0-10 puan "depresyon yok", 11-13 puan "olası depresyon", 14 ve üzeri puan "kesin depresyon" şeklinde yapılmıştır (Aksüllü ve Doğan, 2004).

Rosenberg Benlik Saygısı Ölçeği: İnsan davranışını biçimlendiren en önemli etken, bireyin kendisini ve çevresini o andaki algılayış biçimidir. (Yıldız, 2006). Benlik saygısı, kişinin kendisini sevmesi ve kendisine değer vermesi anlamını içermektedir (Peker, 2008). Her insan kendisini önemli hissetmek ve bir değer sahibi olmak ister. Morris Rosenberg'e göre özsaygı (benlik saygısı), her bireyin kendi değeri hakkında sahip olduğu duygu olup, kişinin "kendini benimsemesi, kendine değer vermesi, güven ve saygı duyması ve bireyin kendisini değerli bulup onaylaması" anlamlarına gelir (Rosenberg, 1965).

Benlik saygısı genel itibariyle yüksek ve düşük olmak üzere iki kategoride değerlendirilir. Yüksek benlik saygısı bireyin kendine güven duyması, becerilerine güvenmesi, düşük benlik saygısı ise bireyin kendini değersiz, başarısız hissetmesi anlamına gelir (Yapıcı ve Kayıklık, 2005). Kişinin kendisini sevilmeye ve değer görmeye layık olarak algılaması şeklinde tanımlanan benlik saygısının düşük ya da yüksek olmasında birçok faktör rol oynamaktadır. Benlik saygısı, insanın biyolojik ve psikolojik yapısı gereği çok çeşitli etkenlerden etkilenen (Koç, 2009; Özkan, 1994; Şahin, 2005) aynı zamanda da insanın bilişsel, duyuşsal, davranışsal ve motivasyonel boyutları üzerinde önemli etkisi olan bir kavramdır. Konuyla ilgili alanyazın göstermektedir ki yüksek benlik saygısı bireyin psikolojik sağlığını olumlu, düşük benlik saygısı ise olumsuz etkilemektedir (Cevher ve Buluş, 2007; Kimter, 2012; Koç, 2008; Yapıc1, 2013). Yüksek benlik saygısına sahip bireyler, kendine saygı duymakta ve kendini değerli görmekte, daha sağlıklı bir ruhsal gelişime sahip olarak topluma katılmakta ve daha mutlu ve daha kaliteli bir yaşama sahip olmaktadırlar (Yıldız ve Çapar, 2010). Benlik saygısı yüksek olan bireylerde yeterli özgüven, iyimserlik, başarma isteği ve stres karşısında direnç gösterebilme özellikleri görülmektedir. Benlik saygısı düşük olan bireylerin özgüven düzeyleri düşük, anksiyeteleri yüksek düzeydedir (Başkara, 2002; Karahan ve ark., 2004). Bu doğrultuda çalışmada huzurevinde kalan yaşlı bireylerin benlik saygısı düzeyleri test edilmek üzere "Rosenberg Benlik Saygısı Ölçeği" uygulanmıştır.

Araştırmada Benlik Saygısı ölçümü için kullanılan ve orijinal formu İngilizce "Rosenberg Self Esteem Scale" ismini taşıyan ölçek, 1963 yılında 
Morris Rosenberg tarafından geliştirilmiştir. ABD'de güvenirlik ve geçerlilik çalışmaları yapıldıktan sonra pek çok araştırmada ölçüm aracı olarak kullanılan ölçek, "Rosenberg Benlik Saygısı Ölçeği”" adı altında Füsun Çuhadaroğlu tarafından Türkçeye uyarlanmıştır (Öner, 1997).

Bugün psikiyatrik ve psikolojik çalışmalarda benlik saygısının ölçümü için kullanılan güvenilir dört ana ölçekten birisi olarak ifade edilen Rosenberg Benlik Saygısı Ölçeği çoktan seçmeli 63 sorudan yapılanmış on iki alt ölçekten oluşmaktadır (Çuhadaroğlu, 1985). Bu araştırmada söz konusu ölçeğin kısa formu olan ve beş olumlu beş olumsuz ifadenin yer aldığı toplam on sorudan oluşan "Benlik Saygısı" alt ölçeği kullanılmıştır.

Rosenberg Benlik Saygısı Ölçeği’nin benlik saygısı alt kategorisi puanlaması ise şu şekildedir:

Rosenberg Benlik Saygısı Ölçeği, Guttman ölçüm şekline göre düzenlenmiş olumlu-olumsuz yüklü 6 madde hâlinde ardışık olarak sıralanmıştır. Bu 6 maddede toplam 10 soru bulunmaktadır. Soruların her biri "çok doğru, doğru, yanlış ve çok yanlış" şeklinde dört şekilde cevaplanabilmektedir. Bu durumda benlik saygisı alt ölçeğinin I. maddesinde toplam üç soru mevcut olup bu sorulardan sadece ikisine doğru cevap vermek bu maddeden 1 puan almak için yeterli olmaktadır. II. maddede toplam iki soru yer almakta olup bu sorulardan sadece birisinden alınan doğru cevap bu maddeden 1 puan almak için yeterli olmaktadır. III, IV ve V. maddelerde sadece birer soru bulunmakta olup bu sorulara verilen her bir doğru cevap için 1 puan alınmaktadır. VI. madde ise toplam iki sorudan oluşmakta olup bu sorulardan sadece birisinden alınan doğru cevap bu maddeden 1 puan almak için yeterli olmaktadır. Böylece benlik saygısı alt kategorisinden 0 ile 6 arasında puan almak mümkün olmaktadır.

Sonuç itibarıyla benlik saygısı alt ölçeğinden alınan puanlar 0-6 arasinda olup; 0-1 puan alanların yüksek, 2-4 puan alanların orta, 5-6 puan alanların ise düşük benlik saygısına sahip oldukları kabul edilmektedir (Öner, 1997).

\section{Veri Toplama Süreci}

Araştırmada ilk olarak anket çalışmasının uygulanacağı huzurevi kurucu müdürü ile görüşülmüşs sonrasında kurumunun bağl1 olduğu Bilecik Aile ve Sosyal Politikalar İl Müdürlüğü ile görüşmeler yapılmış, gerekli resmî izinler alınmıştır. 
Araştırma kapsamında huzurevlerinde kalan fakat yatağa bağımlı olup sürekli bakım gereken, sözel iletişime geçemeyenler araştırmaya dâhil edilmemiştir.

Söz konusu araştırmada güvenilirliği azaltacağı düşüncesiyle, anketör ya da posta yolu tercih edilmemiş, anketin geri dönüş oranını artırmak amacıyla anket uygulaması katılımcılara bizzat araştırmacı tarafından gerçekleştirilmiştir. Anketin uygulanması esnasında katılımcılara anketin amacı ve muhtevası konusunda gerekli açıklamalarda bulunulduktan sonra katılıp katılmama konusunda özgür oldukları belirtilmiş ve çalışmaya katılma hususunda sözlü olarak izinleri alınmıştır. Uygulama esnasında katılımcıların herhangi bir etki altında kalmamalarını sağlamak, böylelikle araştırma sonuçlarının güvenilirliğini artırmak, daha sağlıklı ve güvenilir bilgilere ulaşılabilmesini ve katılımcıların görüşlerini çekinmeden rahatça ifade ederek verilen cevapların daha samimi ve doğru olmasını sağlamak amacıyla uygulamaya katılan yaş11lara elde edilen verilerin bilimsel maksatlar dışında kullanılmayacağı, verdikleri cevapların gizli kalacağı hususunda teminat verilerek kafalarında oluşacak her türlü soru işaretleri giderildikten sonra anket uygulamasına geçilmiş ve böylelikle uygulama sırasında herhangi bir sorunla karşılaşılmamıştır. Veri toplama formları bizzat araştırmacı tarafından araştırmayı kabul eden bireylerle yüz yüze görüşülerek uygulanmıştır. Bu uygulamalardan sonra anket formlarına verilen cevaplardan elde edilen veriler bilgisayara aktarılmıştır. Anket formlarının bilgisayara kaydedilmesinden sonra SPSS programı yard1mıyla tablolar oluşturulmuş ve elde edilen veriler değerlendirilmiştir.

\section{Araştırmanın Veri Analizinde Kullanılan İstatistiksel İşlemler ve Teknikler}

Huzurevinde yaşayan bireylerin depresyon ve benlik saygısı düzeyleri ve sosyo-demografik değişkenlerle ilişkisi üzerine bir alan araştırması konulu bu çalışmanın veri analizinde birçok istatistikî teknikten faydalanılmıştır. Araştırmada ampirik metot seçilmiş olup veri analizinde kullanılan istatistiksel işlemler, ölçeğin tipi ve araştırma hipotezleri dikkate alınarak seçilmiş ve hipotezler bölümünde verilmiş olan hipotezlerin sınanması amaçlanmıştır. $\mathrm{Bu}$ amaç doğrultusunda anketlerin uygulama aşamasından sonra değerlendirmeye alınan anketlerden elde edilen veriler, sosyal bilimlerde psiko-metrik bağlamda yapılan istatistiksel analizlerde sıkça kullanılan "Sosyal Bilimler İçin İstatistik Paket Programı (Statistical Package for the Social Sciences-SPSS For Windows 20.0)" yoluyla bizzat araştırmacı tarafindan bilgisayara 
aktarılmıştır. Bu doğrultuda anket uygulaması neticesinde elde edilen verilerin çözümlenmesinde frekans analizi, yüzdelik hesaplama, aritmetik ortalama ve standart sapma, minimum ve maksimum değerlerini göstermek için ise Descriptive Analizi uygulanmıştır. İki değişken arasındaki ilişkinin yönü ve şiddetini hesaplamak için ise korelasyon analizinden yararlanılmıştır. Kullanılan ölçeklerin araştırmaya katılanların demografik bilgilerine göre farklılık gösterip göstermediği Student $\mathrm{T}$ testi ve $\mathrm{F}$ testleri/Varyans analizi (ANOVA) ile test edilmiştir. Elde edilen veriler \%95'lik (en çok hata pay1 \%5) güven aral1ğında, anlamlılık $p<0.05$ düzeyi esas alınarak değerlendirilmiştir.

\section{Bulgular}

\section{Bireylerin Demografik Özelliklerine İlişkin Bulgular}

Tablo 1. Katılımcıların Demografik Özelliklerine Göre Dă̆ılımı

\begin{tabular}{llcc}
\hline & & $\mathbf{N}$ & $\mathbf{\%}$ \\
\hline Cinsiyet & Kadın & 9 & 30.0 \\
& Erkek & 21 & 70.0 \\
\hline Yaş & $60-70$ & 13 & 43.3 \\
& $71-80$ & 7 & 23.3 \\
& $81-90$ & 9 & 30.0 \\
& $91+$ & 1 & 3.3 \\
\hline Medenî & Bekâr & 4 & 13.3 \\
Durum & Dul (Eşi ölmüş) & 17 & 56.7 \\
& Boşanmış & 9 & 30.0 \\
\hline Eğitim & Okur-yazar değil & 3 & 10.0 \\
Durumu & Okur-yazar & 4 & 13.3 \\
& İkokul & 16 & 53.3 \\
& Ortaokul & 3 & 10.0 \\
& Lise & 2 & 6.7 \\
& Üniversite ve üzeri & 2 & 6.7 \\
\hline Toplam & & 30 & 100.0 \\
\hline
\end{tabular}

Tablo 2. Katılımcıların Kurumdaki Yaşantı ve Sosyal Aktivitelere Katılma Durumu

\begin{tabular}{llcc}
\hline & & $\mathbf{N}$ & $\mathbf{\%}$ \\
\hline Kurumda Kalma & 1 yıldan az & 7 & 23.3 \\
Süresi & 1-3 yıl & 9 & 30.0 \\
& 4-6 yıl & 8 & 26.7 \\
& 7 yıldan fazla & 6 & 20.0 \\
\hline Sosyal Uğraşlara & S1k sik & 2 & 6.7 \\
Katılma İsteği & Bazen & 16 & 53.3 \\
& Hiç & 12 & 40.0 \\
\hline Toplam & & 30 & 100.0 \\
\hline
\end{tabular}


Tablo 3. Katılımcıların Tanıtıcı ve Sağlık Durumlarına İlişkin Özelliklerinin Dağılımı

\begin{tabular}{llcc}
\hline & & N & \% \\
\hline Çocuk Sahibi Olma & Var & 23 & 76.7 \\
Durumu & Yok & 7 & 23.3 \\
\hline Çocuklarla & 2-3 haftada bir & 3 & 13.0 \\
Yüzyüze & Ayda bir & 1 & 4.3 \\
Görüşme Sıklı̆ğı & Ayda birden az & 10 & 43.5 \\
& Hiç & 9 & 39.1 \\
\hline Çocuklarla Telefonla & Haftada bir & 1 & 4.3 \\
Konuşma Sıklığı & 2-3 haftada bir & 4 & 17.4 \\
& Ayda bir & 3 & 13.0 \\
& Ayda birden az & 8 & 34.8 \\
& Hiç & 7 & 30.4 \\
\hline Kronik Hastalık & Hiç & 3 & 10.0 \\
Sahibi Olma Durumu & Bir & 12 & 40.0 \\
& Birden fazla & 15 & 50.0 \\
\hline Sürekli İlaç Kullanım & Var & 29 & 96.7 \\
Durumu & Yok & 1 & 3.3 \\
\hline Toplam & & 30 & 100.0 \\
\hline
\end{tabular}

Tablo 4. Kurumda Kalma Sebebi ve Vakit Geçirme Durumuna Göre Dağılımı

\begin{tabular}{llc}
\hline & & $\mathbf{\%}$ \\
\hline Kurumda Vakit & Dinlenerek & 83.3 \\
Geçirme & Sohbet ederek & 80.0 \\
Durumu & Gezerek/yürüyüş yaparak & 46.7 \\
& Kafeteryada tavla, okey gibi oyunlar oynayarak & 23.3 \\
& Internete girerek & 10.0 \\
& Dinî ibadetleri gerçekleştirerek & 10.0 \\
& El becerisi gerektiren işlerle uğraşarak & 6.7 \\
& Gazete, kitap, dergi okuyarak ve yazı yazarak & 6.7 \\
\hline Kurumda & Kendi bakımını tek başına yapamama & 56 \\
Kalma Sebebi & Kalacak kimsesinin olmaması & 16 \\
& Ekonomik sebepler & 28 \\
\hline Toplam & & 100 \\
\hline
\end{tabular}

Katılımcıların Depresyon/Benlik Saygısı Düzeylerine İlişkin Bulgular

Tablo 5. Ölçeklere Ait Tanımlayıcı İstatistikler

\begin{tabular}{lccccc}
\hline & N & Minimum & Maksimum & Ortalama & ss \\
\hline Geriatric Depresyon Puanı & 30 & 6.00 & 30.00 & 18.53 & 7.16 \\
Benlik Saygıs1 Puanı & 30 & 0.00 & 6.00 & 2.90 & 1.70 \\
\hline
\end{tabular}

Yukarıdaki tabloda araştırmada kullanılan depresyon ve benlik saygısı 
ölçeklerine ait tanımlayıcı istatistikler gösterilmiştir. Tabloda minimum, maksimum, ortalama ve standart sapma değerleri verilmiştir.

Huzurevinde kalan yaşlılara uygulanan depresyon testine göre depresyon düzeyinin yüksek olduğu (ort=18.53 \pm 7.16 ) görülmektedir. Ortalama benlik saygısı puanı $2.9 \pm 1.70$ bulunmuştur. Bu değer huzurevinde kalan yaşlıların benlik saygısının orta düzeyde olduğunu göstermektedir.

Aşağıdaki tablolarda huzurevinde kalan yaşlıların depresyon ve benlik sayg1s1 dağılımı gösterilmiştir.

Tablo 6. Geriatric Depresyon Durumu

\begin{tabular}{lcc}
\hline & N & \% \\
\hline Depresyon Yok & 5 & 16.7 \\
Muhtemel Depresyon & 4 & 13.3 \\
Kesin Depresyon & 21 & 70.0 \\
\hline Toplam & 30 & 100.0 \\
\hline
\end{tabular}

Huzurevinde kalan yaşlıların \%16.7'sinde depresyon görülmemiştir. Yaşl1ların \%13.3'ü muhtemel depresyon belirtisi gösterirken \%70'i de kesin depresyon belirtisi göstermektedir.

Araştırmaya katılan yaşlıların benlik saygıları düzeylerini tespit etmek amacıyla kendilerine yöneltilen Benlik Saygısı Ölçeği sorularına verdikleri yanıtlara göre dağılım oranı aşağıda tablo hâlinde sunulmuştur.

Tablo 7. Benlik Saygisı Durumu

\begin{tabular}{lcc}
\hline & $\mathbf{N}$ & $\mathbf{\%}$ \\
\hline Yüksek & 8 & 26.7 \\
Orta & 16 & 53.3 \\
Düşük & 6 & 20.0 \\
\hline Toplam & 30 & 100.0 \\
\hline
\end{tabular}

Yukarıdaki tabloda Benlik Saygısı Ölçeği’nin gruplanmış frekans ve yüzde değerleri verilmiştir. Huzurevinde kalan yaşlıların benlik saygılarına bakıldığında \%26.7'si yüksek, \%53.3'ü orta, \%20'si de düşük benlik saygıs1 göstermektedir. 


\section{Katılımcıların Depresyon-Benlik Saygısı Karşılıkıı İlişsi Analizine İlişkin Bulgular}

Tablo 8. Geriatric Depresyon ve Benlik Saygısı Arasındaki İlişkiyi Gösteren Korelasyon Analizi

\begin{tabular}{llcc}
\hline & & $\begin{array}{c}\text { Geriatric } \\
\text { Depresyon }\end{array}$ & Benlik Saygısı \\
\hline $\begin{array}{l}\text { Geriatric } \\
\text { Depresyon }\end{array}$ & Korelasyon (r) & 1 & \\
\hline Benlik & Anlaml1lk (P) & & \\
Saygısı & Pearson Correlation & $.635(* *)$ & 1 \\
**Korelasyon 0.01 seviyesinde anlamlidir. *Korelasyon 0.05 seviyesinde anlamlıdır.
\end{tabular}

Yukarıdaki tabloda geriatric depresyon ve benlik saygısı arasındaki ilişki incelenmiştir. Buna göre; geriatric depresyon düzeyi ile benlik saygısı arasında anlamlı bir ilişki vardır $(p<0.05, \mathrm{r}=0.635)$. Düşük benlik (benlik puanı arttıkça benlik saygısı düşmekte) sahipli yaşlıların depresyon düzeyi yüksektir. Yani depresyon ile Benlik Saygısı Ölçeği puanı arasında negatif doğrusal anlamlı bir ilişki vardır. Yani depresyon ortalaması arttıkça Benlik Saygis1 azalmaktadir.

\section{Depresyon-Benlik Saygısı-Demografik Değişkenler Arası Karşılıklı İlişki Analizine İlişkin Bulgular}

Aşağıdaki tablolarda huzurevinde kalan yaşlıların depresyon, benlik saygısının demografik bilgilerine göre farklılık gösterip göstermediği test eden $\mathrm{T}$ ve $\mathrm{F}$ testi sonuçları bulunmaktadır. T testi, iki örneklem grubu arasında ortalamalar açısından fark olup olmadığını araştırmak amacıyla kullanılmıştır. İkiden fazla grubun ortalamaları karşılaştırırken ise F (Varyans) Testi uygulanmıştır.

Tablo 9. Yaşlılarda Depresyon Düzeyi ve Benlik Saygısının Cinsiyete Göre Farklılığının İncelenmesi

\begin{tabular}{llccccc}
\hline & Cinsiyet & N & Ortalama & ss & t & \multirow{2}{*}{$\boldsymbol{~}$} \\
\hline Geriatric & Kadın & 9 & 23.2222 & 4.46592 & \multirow{2}{*}{2.561} & \multirow{2}{*}{0.016} \\
Depresyon & Erkek & 21 & 16.5238 & 7.23615 & & \multirow{2}{*}{0.173} \\
\hline Benlik & Kadın & 9 & 3.5556 & 2.06828 & \multirow{2}{*}{1.398} & \multirow{2}{*}{0.49921} \\
Saygis1 & Erkek & 21 & 2.6190 & 1.4992 &
\end{tabular}

$\% 95$ güven düzeyinde yapılan $t$ testi sonucuna göre depresyon düzeyi kadınlarda (23.22) erkeklere göre (16.52) daha yüksek düzeydedir. Anlamlılık değerinin $p=0.016<0.05$ olmasından dolayı aradaki fark anlamlıdır. Yani, 
geriatric depresyon düzeyi yaşlılarının cinsiyetine göre anlamlı farklılık göstermektedir.

Yaşlıların benlik saygısı durumunun cinsiyete göre farklılı̆̆ını incelemek için yapılan testte ise $p=0.173>0.05$ bulunmuştur. Bu değer benlik saygısının yaşlılarının cinsiyetine göre anlamlı farklılık göstermediğini açıklamaktadır. Yani kadın ve erkeklerde benlik saygısı birbirine yakın düzeydedir.

Tablo 10. Yaşlılarda Depresyon Düzeyi ve Benlik Saygısının Sosyal Uğraşlara Katılma İsteğine Göre Farklılığının İncelenmesi

\begin{tabular}{llccccc}
\hline & $\begin{array}{l}\text { Sosyal Uğraşlara } \\
\text { Katılma }\end{array}$ & $\mathbf{N}$ & Ortalama & ss & t & \multirow{2}{*}{} \\
\hline Geriatric & Bazen & 16 & 15.6250 & 6.85930 & -3.305 & \multirow{2}{*}{0.003} \\
Depresyon & Hiç & 12 & 23.4167 & 5.08935 & & \\
\hline Benlik & Bazen & 16 & 2.1250 & 1.50000 & -3.537 & 0.002 \\
Saygis1 & Hiç & 12 & 4.0833 & 1.37895 & \\
\hline
\end{tabular}

Sosyal uğraşlara hiç katılmayan yaşlıların depresyon düzeyi (23.41), sosyal uğraşlara bazen katılan yaşlılara göre (15.62) daha yüksek düzeydedir. Anlamlılık değerinin $p=0.003<0.005$ olmasından dolayı aradaki fark anlamlıdır. Yani, yaşlıların depresyon düzeyi sosyal uğraşlara katılma durumuna göre anlamlı farklılık göstermektedir.

Sosyal uğraşlara hiç katılmayan yaşlıların benlik saygısı (4.08) diğer yaşl1lara göre (2.12) daha düşüktür (benlik puanı yüksek ise benlik saygısı düşük). Anlamlılık değerinin $p=0.002<0.005$ olmasından dolayı aradaki fark anlamlıdır. Yani, yaşlıların benlik saygısı sosyal uğraşlara katılma durumuna göre anlamlı farkl111k göstermektedir.

\section{Tartışma}

Huzurevindeki araştırmaya katılan yaşlıların \%30'unu kadınlar, \%70'ini de erkekler oluşturmaktadır. Görüldüğü üzere araştırmaya katılan yaşl1ların büyük çoğunluğu erkektir. Erkeklerin sayı olarak kadınlardan çok olması huzurevlerinde yapılan diğer çalışmalarla uyumlu olup ülkemizde yapılan çalışmalardaki oranlara oldukça yakındır (Bahar, Tutkun ve Sertbaş, 2005). Bu bulgu erkeklerin yaşlandıklarında yalnız kalmak istememeleri, yalnız kaldıklarında kendilerine bakmakta güçlük çekmeleri ve bu kişiler için huzurevinin bakım alabilecekleri en uygun ortam olması sebebiyle kurum bak1mını tercih ettiklerini göstermektedir (Bostancı ve Yılmaz, 2002; Demet, Taşkın, Deniz, Karaca ve İçelli, 2002; Sütoluk, Demirhindi, Savaş ve Akbaba, 2004; Şahin ve Yalçın, 2003). 
Huzur evinde kalan yaşlıların yaş dağılımına bakıldığında \%43.3'ünün 60-70 yaş arasında, \%23.3'ünün 71-80 yaş arasında, \%30'unun 81-90 yaş arasinda ve \%3.3'ünün de 91 yaş ve üzerinde olduğu görülmektedir.

Huzurevinde kalan yaşl1ların \%13.3'ünü bekârlar, \%56.7'sini dullar, \%30'unu da boşanmışlar oluşturmaktadır. Görüldüğü üzere bireylerin büyük çoğunluğu dul ve hiç evlenmemiş bekârlardan oluşmaktadır (\%70). Bostancı ve Y1lmaz'ın (2002) Denizli Huzurevi'ndeki 169 birey ile görüşerek yaptıkları çalışmada, \%93.8'inin dul/hiç evlenmemiş olması, bulgularımızı desteklemektedir. Buradan yalnız oluşun huzurevinde yaşama kararını etkilediği, evli olmayan bireylerin (eşi ölmüş, boşanmış/ayrı yaşıyor, hiç evlenmemiş) huzurevlerini daha çok tercih ettikleri söylenebilir.

Araştırmaya katılan yaşlıların eğitim durumlarına bakıldığı zaman \%10'unun okur-yazar olmadığı, \%13.3'ünün okur-yazar, \%53.3'ünün ilkokul eğitimli, \%10'unun ortaokul eğitimli, \%6.7'sinin lise eğitimli, \%6.7'sinin de üniversite ve üzeri eğitimli olduğu görülmektedir. Bu, genellikle öğrenim düzeyi düşük bireylerin kurum yaşamını tercih ettiğini göstermektedir (Demet ve ark., 2002; Maral ve ark., 2001).

Huzurevinde kalan yaşlıların \%76.7'sinin çocuğu varken, \%23.3'ünün çocuğu yoktur. Huzurevinde kalan yaşlıların çocukları ile yüz yüze görüşme s1klığına bakıldığında \%13'ünün 2-3 haftada bir, \%4.3'ünün ayda bir, \%43.5'inin ayda birden az görüştüğü, \%39.1'inin ise hiç görüşmediği anlaş1maktadır. Huzurevinde kalan yaşlıların çocukları ile telefonda görüşme sıklıklarına bakıldığında \%4.3'ünün haftada bir, \%17.4'ünün 2-3 haftada bir, \%13'ünün ayda bir, \%34.8'inin ayda birden az görüştüğü, \%30.4'ünün ise hiç görüşmediği anlaşılmaktadır.

Huzurevinde kalan yaşlıların \%10'unda hiç kronik hastalık yokken, \%40'1nda bir, \%50'sinde de birden fazla kronik hastalık vardır. Görüldüğü üzere yaşlı bireylerin büyük çoğunluğu kronik hastalıklarının olduğunu belirtmiştir. Huzurevinde kalan yaşlıların \%96.7'si sürekli ilaç kullanmaktadır.

Yaşl1ların \%23.3'ü kurumda 1 yıldan az, \%30'u 1-3 yıl arası, \%26.7'si 4-6 y1l aras1 ve \%20'si de 7 yıldan fazla kalmaktadır. Bireylerin huzurevinde kalış sürelerine bakıldığında çoğunluğun (\%53.3) 4 yıldan az süredir huzurevinde kaldıkları görülmüştür. Yaşlıların yarısından çoğunun son üç yıldır kurumda kalıyor olmaları, son yı1larda huzurevlerine talebin arttığının bir göstergesi olabilir. Benzer bir çalışmada Demet ve arkadaşları (2002) bu oranı 
\%64.1 olarak bulmuş ve bunu son yıllarda huzurevine olan talebin arttığı yönünde yorumlamıştır. Yaşlıların kurumda kalış süreleri ile depresyon arasında, istatistiksel yönden anlamlı bir ilişki bulunmamıştır $(p>0.05)$. Ergene'nin çalışmasında da kurumda kalış süresi ile depresyon arasında ilişki bulunmamıştır (Ergene, 1989). Bu bulgu aile çevresinden ayrılan, bazı alışkanlıklarından vazgeçen ve tanımadığı insanlarla yaşamı paylaşan yaşlıların, bu duruma uyum sağladıklarını göstermektedir (Bahar, Tutkun ve Sertbaş, 2005).

Araştırmaya katılan yaşlıların \%6.7'si sık sık sosyal uğraşlara katılma isteği duyarken, \%53.3'ü bazen istek duymakta, \%40'1 ise hiç istek duymamaktadır. Huzurevinde kalan yaşlılar vakitlerini daha çok televizyon izleyerek, radyo dinleyerek, dinlenerek ve sohbet ederek geçirmektedir.

Yaşlıların \%56'sı kendi bakımını tek başına yapamadığı, \%16'sı kalacak kimsesinin olmadığ $1, \% 28$ 'i ise ekonomik sebepler yüzünden kurumda kalmayı tercih ettiklerini ifade etmişlerdir. Bireylerin büyük çoğunluğu (\%56) kuruma gelme nedenini kendi bakımını tek başına yapamama olarak ifade etmiş, \%16'sı hiç kimsesi olmadığı için \%28'i ise ekonomik imkânsızlıklar sebebiyle kurumda kalmayı tercih ettiklerini belirtmişlerdir. Ayrıca dul olma, çocuk sahibi olmama ve sosyoekonomik desteğin olmaması durumları da kurumda kalmayı tercih etmede etkili olabilir. Alanyazında bireylerin, aile ve arkadaşların kaybıyla gelen yalnızlık, ilgilenecek kimsenin olmaması, yalnız yaşayamama, bakacak kimselerinin olmaması, ekonomik problemler ve çekirdek aile yapısının giderek artmasının getirdiği sorunlar gibi nedenlerden dolayı huzurevlerini tercih ettikleri belirtilmektedir (Yazıc1, 1994). Alanyazın bilgileri çalışma bulgumuzu desteklemektedir.

Huzurevinde kalan yaşlilara uygulanan depresyon testine göre depresyon düzeyinin yüksek olduğu (ort=18.53 \pm 7.16 ) görülmektedir. Huzurevinde kalan yaşl1ların \%16.7'sinde depresyon görülmemiştir. Yaşlıların \%13.3’ü muhtemel depresyon belirtisi gösterirken \%70'i de kesin depresyon belirtisi göstermektedir. Ülkemizde yapılan pek çok çalışmada huzurevinde kalan yaşlılarda depresyon yaygınlığının yüksek olduğu bildirilmiştir. Huzurevinde yaşayan yaşlılardaki depresyon sıklığı Maral ve arkadaşlarının (2001) yaptığı çalışmada (\%47.6) bulunmuştur. Altay ve Avcı da (2009) kurumda yaşayan yaşlılarda depresyon sıklığını \%62.5 olarak bildirmişlerdir. Topbaş, Yaris, Can, Kapuca ve Sayar (2004) ise \%80.4 olarak bulmuşlardır. Yine ülkemizde yapılan başka bir araştırmaya göre ise, huzurevinde yaşayan yaşlı bireylerin 
depresyon yaygınlıkları incelendiğinde, yaşl1ların \%55'inde depresyon görüldügü saptanmıştır (Hacıhasanoğlu ve Yıldırım, 2009). Ayrıca Aksüllü ve Doğan'ın (2004) yaptıkları çalışmada da \%68.9 oranında depresyon saptanmıştır. Görüldüğü üzere araştırma bulgusu diğer araştırma bulguları ve alanyazındaki oranlar ile benzerlik göstermektedir. Elde edilen bu veriler "Huzurevinde kalan yaşlı bireylerin depresyon düzeyleri yüksektir.” şeklindeki hipotezimizi (Hipotez 3) doğrulamaktadır.

Huzurevinde kalan yaşl1lara uygulanan Rosenberg Benlik Saygısı testine göre yaşlıların ortalama benlik saygısı puanı $2.9 \pm 1.70$ bulunmuştur. Huzurevinde kalan yaşlıların benlik saygılarına bakıldığında \%26.7'si yüksek, \%53.3'ü orta, \%20'si de düşük benlik saygısı göstermektedir. Bu değerler huzurevinde kalan yaşlıların büyük çoğunluğunun benlik saygısının orta düzeyde olduğunu göstermektedir.

Bu çalışmada ayrıca sosyo-demografik özelliklerin depresyon ve benlik saygısı ile ilişkileri de incelenmiştir. Yapılan analizler sonucunda araştırmada $\% 95$ güven düzeyinde yapılan $t$ testi sonucuna göre depresyon ve benlik sayg1sı düzeylerinin, yaşlı bireylerin yaş, medenî durum, en uzun süre yaşadığı yer, eğitim durumu, gelir durumu, kurumda kalma süresi, çocuğu olup olmama durumu, çocuklarla görüşme sıklığı (yüz yüze/telefonla), meslek dağ1lımı, herhangi bir sosyal güvence durumu, ziyaret edilme sıklığı, odayı paylaşma durumu, kurumda kalma sebebi, kurumda vakit geçirme durumu, kronik hastalık durumu, sürekli ilaç kullanım durumlarına göre anlamlı bir farklı1ık/ilişki gözlenmediği ( $p>0.05)$, sınırlı sayıda sosyo-demografik değişken ile geriatrik depresyon ve benlik saygısı arasında ilişki olduğu tespit edilmiştir. Bu bulgulardan hareketle "Huzurevinde kalan yaşl1 bireylerin depresyon ve benlik saygısı düzeyi ile sosyo-demografik değişkenler arasında anlamlı bir ilişki/farklılık olması beklenmektedir." şeklindeki hipotezimiz (Hipotez 2) kısmen doğrulanmıştır.

Burada şunu belirtmek gerekir ki benlik saygisı-depresyon-demografik değişkenler arasında ilişkinin yönünü ve düzeyini tespit etmeye yönelik gerçekleştirilen çeşitli araştırmalarda farklı türden ilişkiler ve farklı sonuçlar elde edildiği bilinmektedir. Bu farklılıklar depresyon ile benlik saygısı arasındaki ilişkinin tek boyutlu olmamasından, sosyo-kültürel çevre farkl1l1klarından, seçilen örneklem grubunun özelliklerinden, bu konuda kullanılan farklı ölçek türlerinden kaynaklanabilmektedir.

Bilecik Huzurevi'nde yaşayan yaşlı bireylerin depresyon ve benlik 
saygıları, demografik değişkenler ile depresyon/benlik saygısı arasındaki karş1ıklı ilişkilerin incelendiği bu araştırmada şu bulgular elde edilmiştir:

$\% 95$ güven düzeyinde yapılan $\mathrm{t}$ testi sonucuna göre geriatric depresyon düzeyi yaşlıların cinsiyetine göre anlamlı farklılık göstermektedir. Depresyon düzeyi kadınlarda (23.22) erkeklere göre (16.52) daha yüksek düzeydedir. Anlamlılık değerinin $p=0.016<0.05$ olmasından dolayı aradaki fark anlamlıdır. Toplumda depresyonun kadınlarda daha sık olduğu bilinmektedir (Çifçili, Yazgan ve Ünalan, 2006; Zincir ve ark., 2008). Dişcigil, Gemalmaz, Başak, Gürel ve Tekin (2005) tarafından yapılıış bir çalışmada kadınlarda erkeklerden daha fazla depresyon olduğu ve depresyon riskinin kadınlarda daha yüksek olduğu saptanmıştır. Maral ve arkadaşları (2001) tarafindan yapılan bir çalışmada da huzurevinde yaşayan kadınlarda depresyonun erkeklerden daha fazla olduğu bulunmuştur. Bizim çalışmamızda da huzurevinde kalan kadınların depresyon düzeyleri ile erkeklerin depresyon düzeyleri arasında anlamlı farklılık saptanmıştır $(p<0.05)$. Araştırma bulgusu diğer araştırma bulguları ile benzerlik gösterirken aynı zamanda literatür bilgisini desteklemiştir. $\mathrm{Bu}$ sonuca göre, "Huzurevlerinde kalan yaşlı bayanların depresyon düzeyi erkeklere göre daha yüksek düzeydedir.” şeklindeki hipotezimiz (Hipotez 4) doğrulanmıştır.

Yaşl1ların benlik saygısı durumunun cinsiyete göre farklılığını incelemek için yapılan testte ise $p=0.173>0.05$ bulunmuştur. Bu değer benlik saygısının yaşlılarının cinsiyetine göre anlamlı farklılık göstermediğini açıklamaktadır. Yani kadın ve erkeklerde benlik saygısı birbirine yakın düzeydedir.

Yaşl1ların depresyon düzeyi sosyal uğraşlara katılma durumuna göre anlamlı farklılık göstermektedir $(p=0.003<0.005)$. Buna göre sosyal uğraşlara hiç katılmayan yaşlıların depresyon düzeyi (23.41), sosyal uğraşlara bazen katılan yaşlılara göre (15.62) daha yüksek düzeydedir. Anlamlılık değerinin $p=0.003<0.005$ olmasından dolayı aradaki fark anlamlıdır. Etkinliklere katılma, depresyonu önleyen bir etkendir. Bu durum, Sütoluk ve arkadaşları (2004) ile Demet ve arkadaşlarının (2002) çalışmalarında da görülmektedir.

Yaşlıların benlik saygısı sosyal uğraşlara katılma durumuna göre anlamlı farklılık gösterir. Sosyal uğraşlara hiç katılmayan yaşlıların benlik sayg1s1 (4.08) diğer yaşlilara göre (2.12) daha düşüktür (benlik puanı yüksek ise benlik saygısı düşük). Anlamlılık değerinin $p=0.002<0.005$ olmasından dolayı aradaki fark anlamlıdır. 
Son olarak geriatrik depresyon düzeyi ile benlik saygısı düzeyleri arasında ilişkinin olup olmadığı, ilişki var ise bu ilişkinin yönü ve düzeyi ile ilgili ilişki analizi incelendiğinde şu sonuç elde edilmiştir:

Geriatric depresyon düzeyi ile benlik saygısı arasında anlamlı bir ilişki vardır $(p<0.05, \mathrm{r}=0.635)$. Düşük benlik (benlik puanı arttıkça benlik saygısı düşmekte) sahipli yaşlıların depresyon düzeyi yüksektir. Yani depresyon ile Benlik Saygısı Ölçeği puanı arasında negatif doğrusal anlamlı bir ilişki vardır. Yani depresyon ortalaması arttıkça benlik saygısı azalmaktadır. Böylelikle, "Huzurevinde kalan yaşlı bireylerin depresyon düzeyleri ile benlik saygısı düzeyleri arasında negatif yönde anlamlı bir ilişki vardır." şeklindeki hipotezimiz (Hipotez 1) analiz sonuçlarına göre doğrulanmıştır.

\section{Sonuç ve Öneriler}

Araştırmanın konusu, yaşlıların depresyon ile benlik saygısı düzeyleri arasında nasıl bir ilişki olduğudur. Bunun yanında araştırmanın bağımsız değişkenleri olarak kabul edilen sosyo-demografik değişkenler ile depresyon ve benlik saygısı arasındaki ilişki veya farklılıkları sorgulamak da amaçlanmıştır.

$\mathrm{Bu}$ araştırma ile huzurevinde yaşayan yaşlılar ile ilgili önemli veriler elde edilmiş ve araştırma bulguları sonucunda;

1. Huzurevinde kalan yaşlı bireylerin depresyon düzeyinin yüksek olduğu (18.53 \pm 7.16$)$, yaşl1ların \%70'inin kesin depresyon belirtisi gösterdikleri ve depresyon düzeyinin kadınlarda (23.22) erkeklere göre (16.52) daha yüksek düzeyde olduğu,

2. Kişinin kendini değerli görme, kendinden memnun olma, kendine karşı olumlu tutum içerisinde olma gibi özelliklerini içeren benlik saygısı ile depresyon arasında negatif anlamlı bir ilişkinin olduğu $(p<0.05, \mathrm{r}=0.635)$, huzurevinde kalan yaşlıların depresyon düzeyleri yükseldikçe, benlik saygısı düzeylerinin düştüğü, depresyon düzeyinin artmasının benlik saygılarına olumsuz yönde etki ettiği,

3. Huzurevinde yaşayan yaşlı bireylerin depresyon düzeylerinin sosyal uğraşlara katılma durumuna göre anlamlı farkl11ı gösterdiği $(p=0.003<0.005)$, sosyal uğraşlara hiç katılmayan yaşlıların depresyon düzeyinin (23.41), sosyal uğraşlara bazen katılan yaşlılara göre (15.62) daha yüksek düzeyde olduğu $(p=0.003<0.005)$,

4. Huzurevinde kalan yaşlılardan benlik saygısı düzeyinin sosyal 
uğraşlara katılma durumuna göre anlamlı farklılık gösterdiği $(p=0.002<0.005)$, sosyal uğraşlara hiç katılmayan yaşlıların benlik saygısının (4.08) diğer yaşl1lara göre (2.12) daha düşük düzeyde olduğu tespit edilmiştir.

Huzurevinde kalan yaşlılarda depresyon ile benlik saygısı arasındaki ilişkilerin incelendiği bu çalışmanın sonuçlarıyla ilgili gelinen bu son noktada bazı önerilerde bulunmak istiyoruz.

1. Bu çalışma sonuçları, huzurevinde yaşayan yaşlılara hizmet sunan Aile ve Sosyal Politikalar Bakanlığı, İl Müdürlükleri ve Huzurevi Kurumu yöneticileri ile paylaşılmalıdır.

2. Huzurevi yöneticileri, sağlık ekibi üyeleri ve psikologlarının depresyon yönünden yaşl1ları yakın takibe almasının,

3. Yaş1 larının yükselmesine yönelik olarak bireylerin boş zamanlarını değerlendirebilmeleri için sosyal etkinlikler planlanmasının,

4. Bireylerin sosyalizasyonunu artırmaya yönelik sosyal, kültürel programların düzenlenmesiyle yaşlı bireylerin bu tarz sosyal faaliyetlere aktif katılımlarının sağlanmasının depresyonun önlenmesi, var olan depresyon düzeyinin de aşağıya çekilmesi için olumlu yönde etki edeceği düşünülmektedir.

\section{Kaynakça}

Aksüllü, N. ve Doğan, S. (2004). Huzurevinde ve evde yaşayan yaşlılarda algılanan sosyal destek etkenleri ile depresyon arasındaki ilişki. Anadolu Psikiyatri Dergisi, 5(2), 76-84.

Altay, B. ve Avcı, İ. (2009). Samsun Huzurevi'nde yaşayan yaşlıların bazı özellikleri ile depresyon riski arasındaki ilişki. Turkish Journal of Geriatrics, 12(3), 147-155.

Bahar, A., Tutkun, H. ve Sertbaş, G. (2005). Huzurevinde yaşayan yaşlıların anksiyete ve depresyon düzeylerinin belirlenmesi. Anadolu Psikiyatri Dergisi, 6, 227-239

Baripoğlu, K. (2008). Geriatrik depresyon. R. Mas, I. A. Turan, A. Karan, T. Beğer, Ş. Akman ve Ü. M. Tahir, (Ed.), Geriatri (Cilt II) içinde (109798). Ankara: Fersa Matbaacilik.

Başkara, S. V. (2002). Öz-saygının bazı değişkenler açısından incelenmesi. 
Yayınlanmamış yüksek lisans tezi, Ankara Üniversitesi S. B. E.

Büyüköztürk, Ş., Akgün, E. Ö., Karadeniz, Ş., Demirel, F. ve Çakmak, E. K. (2014). Bilimsel araştırma yöntemleri. Ankara: Pegem Akademi Yayınlar1.

Cevher, F. N. ve Buluş, M. (2007). Benlik kavramı ve benlik saygısı önemi ve geliştirilmesi. Akademik Dizayn Dergisi, 2, 57-58

Çifçili, S., Yazgan, Ç. ve Ünalan, P. (2006). Bir huzurevinde depresyon taramas1 sonuçları. Turkish Journal Of Geriatrics, 9(3), 122-125.

Çuhadaroğlu, F. (1985). Gençlerde benlik saygısı ile ilgili bir araştırma, XXI. Ulusal Psikiyatri ve Nörolojik Bilimler Kongresi Bilimsel Çalışmaları.

Demet, M. M., Taşkın, O., Deniz, F., Karaca, N. ve İçelli, İ. (2002). Manisa huzurevlerinde kalan yaşlılarda depresyon belirtilerinin yaygınlığg ve ilişkili risk etkenleri. Türk Psikiyatri Dergisi, 13, 290-299.

Dişçigil, G., Gemalmaz, A., Başak, O., Gürel, S. F. ve Tekin, N. (2005). Birinci basamakta geriatrik yaş grubunda depresyon. Turkish Journal of Geriatrics, 8(3), 129-133.

Ergene, E. (1989). Huzurevinde yaşayan yaşlıların agresyon ve depresyon düzeylerinin araştırılması. Yayınlanmamış yüksek lisans tezi, Uludağ Üniversitesi, Sağlık Bilimleri Enstitüsü.

Ertan, T., Eker, E. ve Şar, V. (1997). Geriatrik depresyon ölçeğinin Türk yaşlı nüfusunda geçerlik ve güvenirliği. Nöropsikiyatri Arşivi, 34(1), 62-71.

Hacıhasanoğlu, R. ve Yıldırım, A. (2009). Erzincan Huzurevi'nde yaşayan yaşl1larda depresyon ve etkileyen faktörler. Turkish Journal of Geriatrics, 12(1), 25-30.

Karahan, T. F., Sardoğan, M. E., Şar, A. H., Ersanlı, E. ve Kumcağız, H. (2004). Üniversite öğrencilerinin yalnızlık düzeyleri ile benlik saygısı düzeyleri arasındaki ilişkiler, Ondokuz Mayıs Üniversitesi Eğitim Fakültesi Dergisi, 18, 28.

Karasar, N. (2005). Bilimsel araştırma yöntemi (14.baskı). Ankara: Nobel Yayın ve Dağıtım.

Kimter, N. (2012). Ergenlerde benlik saygısının ve öznel dindarlık algısının bazı değişkenler açısından incelenmesi. Mustafa Kemal Üniversitesi 
Sosyal Bilimler Enstitüsü Dergisi, 9(1), 439-468.

Kimter, N. (2012). Benlik saygısı ve din: Üniversiteli gençlerde öz saygı ve din üzerine ampirik bir araştırma. İstanbul: Kriter Yayınevi.

Koç, M. (2008). Yetişkinlik döneminde dindarlık ile benlik kavramı değişkenleri arasındaki ilişki. Yayınlanmamış doktora tezi, Uludağ Üniversitesi, S.B.E.

Koç, M. (2009). Dindarlık ile benlik saygısı arasındaki ilişki: Yetişkinler üzerine ampirik bir araştırma. U.Ü. Illâhiyat Fakültesi Dergisi, 18(1), 473493.

Maral, I., Aslan, S., İlhan, M. N., Yıldırım, A., Candansayar, S. ve Bumin, M. A. (2001). Depresyon yaygınlığ 1 ve risk etmenleri: Huzurevinde ve evde yaşayan yaşlılarda karşılaştırmalı bir çalışma. Türk Psikiyatri Dergisi, 12(4), 251-259.

Öner, N. (1997). Türkiye'de kullanılan psikolojik testler (3.baskı). İstanbul: Boğaziçi Üniversitesi Yayınları.

Özkan, İ. (1994). Benlik saygısını etkileyen etkenler. Düşünen Adam Psikiyatri ve Nörolojik Bilimler Dergisi, 7(3), 4-9.

Peker, H. (2008). Din psikolojisi (2.baskı). İstanbul: Çamlıca Yayınları.

Rosenberg, M. (1965). Society and the adolescent self image. New Jersey: Princeton University Press.

Sağduyu, A. (1997). Yaşlilar için depresyon ölçeği: Hamilton depresyon ölçeği ile karşılaştırmalı güvenilirlik ve geçerlilik çalışması. Türk Psikiyatri Dergisi, 8, 3-8.

Sütoluk, Z., Demirhindi, H., Savaş, N. ve Akbaba, M. (2004). Adana huzurevlerinde kalan yaşl1larda depresyon sıklığ 1 ve nedenleri. Türk Geriatri Dergisi, 7, 148-151.

Şahin, M. ve Yalçın, M. (2003). Huzurevinde veya kendi evlerinde yaşayan yaşlılarda depresyon sıklıklarının karşılaştırılması. Türk Geriatri Dergisi, 6, 10-13.

Şahin, Â. (2005). Ergenlerde dindarlık-benlik saygısı ilişkisi. Selçuk Üniversitesi Illahiyat Fakültesi Dergisi, 19, 187-197.

Topbaş, M., Yaris, F., Can, G., Kapuca, M. ve Sayar, K. (2004). The effect of 
sociodemographic factors and medical status on depressive symptoms of the inhabitants of nursing home and communitydrewelling elders in Trabzon-Turkey. Klinik Psikofarmakoloji Bülteni, 14, 57-60.

Yapıcı, A. ve Kayıklık, H. (2005). Ruh sağlığı bağlamında dindarlığın özsaygı ve kaygi ile ilişkisi (Çukurova Üniversitesi Örneği). Değerler Eğitimi Dergisi, 3(9), 177-206.

Yapıc1, A. (2013). Ruh sağlığı ve din: psiko-sosyal uyum ve dindarlı (2.bask1). Adana: Karahan Kitabevi.

Yazıc1, R. (1994). Yaşlı bireylerin ölüm kaygısı ve bunun günlük yaşam aktivitelerine olan etkisinin araştırllması. Yayınlanmamış yüksek lisans tezi, İstanbul Üniversitesi Sağlık Bilimleri Enstitüsü.

Yesavage, J. A., Brink, T. L., Rose, T. L., Lum, O., Huang, V., Adey, M. ve Leirer, V. O. (1983). Development and validation of a geriatric depression screening scale: a preliminary report. Journal of Psychiatric Research, 17, 37-49.

Yıldız, M. (2006). Dinsel yönelim biçimleri ve bazı demografik değişkenler açısından üniversite öğrencilerinin benlik-tasarımları üzerine bir araştırma. Tabula Rasa, 6(17), 81-102.

Yıldız, A., Erol, S. ve Ergün, A. (2009). Bir huzurevinde kalan yaşlılarda ağrı ve depresyon riski. Turkish Journal of Geriatrics, 12(3), 156-162.

Yıldız, M. ve Çapar, B. (2010). Orta öğretim öğrencilerindeki benlik saygısı ile dindarlık arasındaki ilişkinin incelenmesi. Din Bilimleri Akademik Araştırma Dergisi, 10(1), 103-131.

Zincir, H., Taşç1, S., Erten, K. Z. ve Başer, M. (2008). Huzurevinde yaşayan yaşlı bireylerin yaşam kalitesi ve depresyon düzeyleri ve etkileyen faktörler. Erciyes Üniversitesi Sağlık Bilimleri Dergisi, 17(3), 168-174. 